\title{
Rencana Operasi dan Pengembangan Produk
}

\author{
Jonathan William Gunawan \\ Program Studi Kewirausahaan \\ Universitas Bina Nusantara \\ jonathan.gunawan004@binus.ac.id
}

\section{Pengantar}

Merencanakan operasi perusahaan dan pengembangan produk bukanlah hal yang bisa dipandang sebelah mata. Jalannya pengeoperasian perusahaan harus diperkirakan matang-matang dan sangatlah penting bagi jalannya segala aktivitas perusahaan. Sama halnya dengan pengembangan produk dimana desain produk merupakan hal yang sangat penting dalam bidang manufaktur. Pengusaha di era modern adalah seorang individu yang memperkenalkan sesuatu yang baru dalam ekonomi atau metode produksi yang belum diuji oleh pengalaman di cabang manufaktur yang bersangkutan, produk yang belum dikenal konsumen, sumber baru bahan baku atau pasar baru dan kehidupan (Purnomo et al., 2020). Desain produk yang baik akan dapat meningkatkan jumlah dan harga jual dari produk, sehingga dapat meningkatkan keuntungan. Akan tetapi, desain produk yang gagal mengakibatkan produk tidak terjual. Hal ini, akan menimbulkan kerugian tidak hanya di bidang desain saja, bidang yang lain pun akan terkena pengaruhnya. Desain produk yang baik, harus memenuhi 3 (tiga) aspek penting yang sering disebut segitiga aspek produk, yaitu kualitas yang baik, biaya rendah, dan jadwal yang tepat. Operation plan and product development (Wheelwright \& Clark, 1992).

\section{Produk}

Produk merupakan sesuatu yang dijual oleh perusahaan kepada pembeli. Pengembangan produk merupakan serangkaian aktivitas yang dimulai dari analisis persepsi dan peluang pasar, kemudian diakhiri dengan tahap produksi, penjualan, dan pengiriman produk. Kesuksesan ekonomi suatu perusahaan manufaktur tergantung kepada kemampuan untuk mengidentifikasi kebutuhan pelanggan, kemudian secara cepat menciptakan produk yang dapat memenuhi kebutuhan tersebut dengan biaya yang rendah. Hal ini bukan merupakan tanggung jawab bagian pemasaran, bagian manufaktur, atau bagian desain saja, melainkan merupakan tanggung jawab yang melibatkan banyak fungsi yang ada di perusahaan. Metode pengembangan produk berdasarkan kepada permintaan atau persyaratan serta spesifikasi produk oleh customeradalah metode yang cukup baik, karena dengan berbasis keinginan customer maka kemungkinan produk tersebut tidak diterima oleh customer menjadi lebih kecil. 


\section{Penilaian Produk}

Ada beberapa faktor yang dapat digunakan untuk menilai suatu produk, sebagai berikut.

1. Kualitas Produk

Bagaimana kualitas produk serta bagaimana produk tersebut dapat berguna bagi masyarakat. Dengan meningkatnya jumlah penjualan maka dapat disimpulkan bahwa kualitas produk tersebut sudah layak dijual di pasaran.

2. Biaya Produk

Biaya untuk modal peralatan dan alat bantu serta biaya produksi setiap unit disebut biaya manufaktur dari produk. Biaya produk menentukan berapa besar laba yang dihasilkan oleh perusahaan pada volume penjualan dan harga penjualan tertentu.

3. Biaya Pengembangan

Biaya pengembangan biasanya merupakan salah satu komponen yang penting dari investasi yang dibutuhkan untuk mencapai profit.

4. Kapabilitas Pengembangan

Kapabilitas pengembangan merupakan aset yang dapat digunakan oleh perusahaan untuk mengembangkan produk dengan lebih efektif dan ekonomis dimasa yang akan datang.

\section{Kesimpulan}

Tidaklah mudah untuk merencanakan operasional perusahaan dan mengembangkan produk. Karena ada, banyak hal yang perlu dipertimbangkan terlebih dahulu.

\section{References}

Barringer, B. R. (2015). Preparing Effective Business Plans: An Entrepreneurial Approach (2nd ed.). Pearson Education Limited.

Purnomo, A., Sudirman, A., Hasibuan, A., Sudarso, A., Sahir, S. H., Salmiah, Mastuti, R., Chamidah, D., Koryati, T., \& Simarmata, J. (2020). Dasar-Dasar Kewirausahaan: untuk Perguruan Tinggi dan Dunia Bisnis. Yayasan Kita Menulis.

https://kitamenulis.id/2020/04/06/dasar-dasar-kewirausahaan-untuk-perguruantingi-dan-dunia-bisnis/

Wheelwright, S.C., \& Clark, K.B. (1992, March). Creating Project Plans to Focus Product Development. Harvard Business Review. https://hbr.org/1992/03/creating-projectplans-to-focus-product-development 


\section{Biografi}

\section{Jonathan William Gunawan}

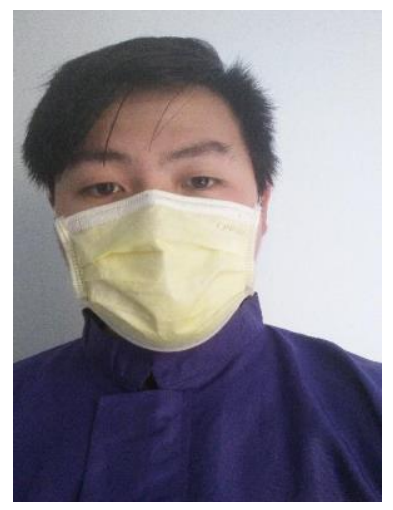

Penulis kelahiran Surabaya ini adalah seorang mahasiswa program studi kewirausahaan di Universitas Bina Nusantara, kampus Malang sejak tahun 2020. Jonathan sedang menjalankan rintisan wirausaha YukSehat yang bergerak di bidang F\&B.

Email: jonathan.gunawan004@binus.ac.id Instagram: jonathannwilliam28_ 